\title{
WOMEN AND MEN IN SENIOR MANAGEMENT - KEY RECURRING THEMES AND QUESTIONS
}

Nowadays, questions on the low female participation in senior management are considered and analysed not only within the academic community, but are also discussed and debated by politicians and business representatives. The purpose of this article is to provide an overview of the key issues and possible approaches to the topic. In the first part, the author focuses on leadership styles: contemporary issues, theoretical considerations and empirical research results. Based on the findings that support the comparative advantages of diverse leadership teams, the author deals with the recommendations on the optimal gender composition of senior management teams. As empirical data are not in line with the recommendations, the author draws attention to the challenges related to talent recognition in the case of potential women leaders and the unequal opportunities in manager selection, such as important factors of low female representation in senior management. Academic articles on terminology, alternative values, special contributions, meritocracy and the social and cultural aspects of unequal opportunities are covered in order to highlight the main factors of the topics discussed.

\section{Keywords: gender, corporate governance, management, leadership}

Nowadays, questions regarding the low female participation in senior management are considered and analysed not only within the academic community, but are also discussed and debated by politicians and business representatives. The issue has been put on the agenda in the EU and has received growing attention in other countries including the USA. A number of aspects from political and economic considerations to leadership and moral concerns are included. Because of the interdisciplinary nature of the topic of female participation in senior management a number of scientific research deals with different aspects of the issue.

Developments within gender and management research were achieved in 'waves' (Broadbridge - Simpson, 2011). Each 'wave' of gender and management research builds on and helps transform the issues raised by the predecessors (Marshall, 1995).

This article discusses how these processes continue to surface in current research. Research papers on the topic emerge from an interdisciplinary academic community, across the fields of psychology, sociology, leadership, management, corporate governance, gender, finance, law, ethics, and entrepreneurship (Powell, 2012). When reviewing the literature on gender issues, I talk not only about the thesis of the 'feminization' of management, but also of the 'remasculinization' of manage-

ment. This suggests that 'feminine' practices and values are being brought back into the masculine domain.

The structure of the article follows the analytical framework developed by Alvesson - Billing (1997) which summarizes some dimensions of the complex relations between women and management (Figure 1). Although the title does not refer to men, because of the comparative perspective of the framework good opportunuties are provided to involve men, too, in the analysis.

Figure 1

Approaches to analysing the relationship between women and management

(Source: Alvesson - Billing, 1997, p.171.)

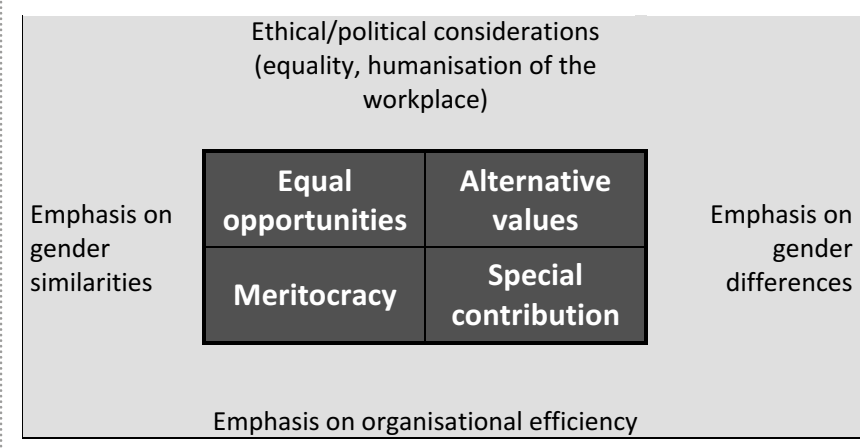

VEZETÉSTUDOMÁNY 
Beginning with the definition of some key terms, the article follows the structure of the matrix. Starting with the issues related to gender differences that can enhance organization efficiency (the lower right corner of the table) and continuing with the alternative values represented by female stereotypes (the upper right corner), I summarize the potential special contributions that can be provided by women in management teams. Further to the qualitative analysis results, quantitative analyses are also summarized to assess the optimal gender composition of 40-60 per cent of senior leadership teams.

Empirical facts based on statistics published in October 2014 show that women accounted for only three percent of CEOs and 13 percent of senior executives in Europe's stock exchange listed blue chip companies (Figure 2).

Figure 2

Share of women amongst senior executives of large listed companies (Source: Eurostat, 2015)

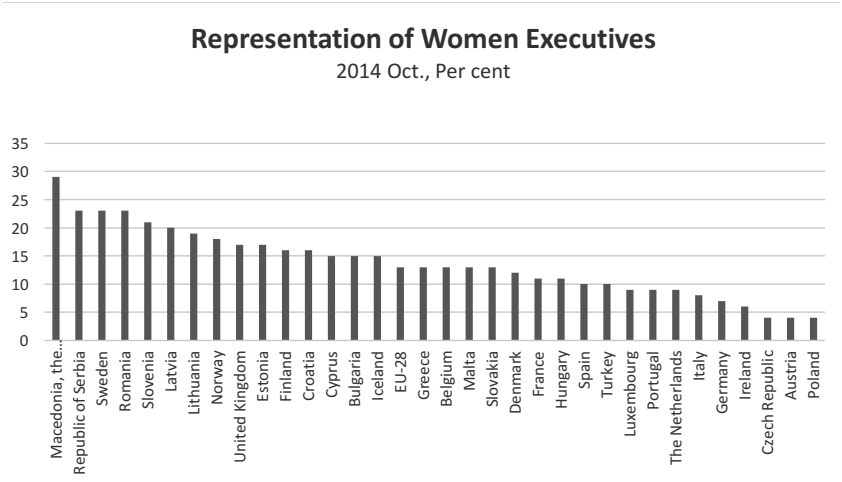

In order to investigate the reasons why reality falls so far from the theoretical optimum, issues of deficiencies in the application of meritocracy and the lack of equal opportunities (the left side of the matrix) are discussed in the final two sections of this article.

\section{Basic concepts, definitions}

In order to provide clear distinctions between the everyday meanings and terminological interpretations of terms, definitions were defined for the concepts of sex (Broadbridge - Hearn, 2008), gender (Unger, 1979; Calás - Smircich, 1996; Archer - Lloyd, 2002; Powell - Graves, 2003; Lippa, 2005), gender stereotypes (Gherardi, 1994; Kite et al., 2008) and gender roles (Eagly et al., 2000; Wood - Eagly, 2010).

\section{Gender and Sex}

Terminology was defined to allow the analysis of male and female issues in a socio-economic context. The term 'sex' is generally used to refer primarily to the categories of male and female (in a wider sense, the term 'sex' also covers other forms of identities or personal preferences). 'Sex' refers to people's biological characteristics that denote their physiological makeup and reproductive status (Powell - Graves, 2003), while 'gender' is a societal and cultural construction and, therefore, refers to more than just biological sex (Broadbridge - Hearn, 2008). In other words, the term 'gender' is applied mostly as a socio-cultural construction (Calás - Smircich, 1996) of the categories 'masculine' and 'feminine' based on what society culturally considers to be appropriate attributes and behaviour for a man or a woman (Unger, 1979). Furthermore 'gender' is used to refer to the psychosocial implications of being male or female, such as beliefs and expectations about the kinds of attitudes, values, skills and behaviours appropriate for or typical of one sex as opposed to the other (Archer - Lloyd, 2002; Lippa, 2005) including feelings, behaviour and interests.

\section{Gender stereotypes and gender roles}

"We "do gender" while we are at work, while we produce an organizational culture and its rules governing what is fair in the relationship between the sexes' (Gherardi, 1994, p. 591.). In this framework stereotypes and roles are frequently used concepts (Eagly et al., 2000; Kite et al., 2008; Wood - Eagly, 2010).

Gender stereotypes represent beliefs about the psychological traits that are characteristic of the members of each sex, whereas gender roles represent beliefs about the behaviours that are appropriate for members of each sex. In the same vein, leader stereotypes represent beliefs about the psychological traits that are characteristic of leaders, whereas leader roles represent beliefs about the behaviours that are appropriate for leaders. In order to reduce dimensions, in most cases, I use the terms of 'leader' (a person who provides vision, aligns, inspires and motivates people), 'leadership' and 'manager' (someone who deals with complexity, plans, manages and controls), 'management' (Kotter, 2001) interchangeably.

\section{Special contribution potential: feminine leadership culture as comparative advantage (the lower right corner of the matrix, see Table 1)}

The study of sex differences in leadership examines how male and female leaders actually differ in attitudes, values, skills, behaviours, and effectiveness, whereas the study of gender differences in leadership focuses on how people believe that male and female leaders differ (Powell, 2012). The 'special contributions' approach indicates that 'femininity' is an asset that holds 
potential advantage in the workplace inverting the value given to difference in the management context. This kind of 'feminization of management' (Fondas, 1997) highlights a style that is oriented towards participation, power sharing and information exchange while it emphasises the differences as compared to other styles.

The similarities and differences given in Table 1 along the horizontal dimension are of equal importance, none of the factors can be ignored. As Judy Wajcman writes, "It is naive to believe that the revaluing of women's 'difference' will succeed where 'equal' opportunities have failed. Indeed, a stress on such differences can easily slide into reinforcing traditional stereotypes of women managers and gender differences more generally. Whichever way women play it, we will never make the grade as men" (2011, p. 347.).

Comparing leadership styles, Eagly and Johnson (1992) distinguished between two approaches: the way in which managers influence the actions of their subordinates and the manner in which they make decisions. In the first approach, two distinct types of behaviour were identified: the 'task' oriented style (this refers to the extent to which the manager initiates and organises work activity and defines the way work is to be done) and the 'interpersonal' style (which refers to the extent to which the manager engages in activities that tend to the morale and welfare of people). The masculine stereotype is associated with a high propensity to exhibit task-oriented behaviours, such as, setting goals and initiating work activity, while the feminine stereotype is associated with a high propensity to exhibit interpersonally-oriented behaviours, such as, showing consideration towards subordinates and demonstrating concern for their satisfaction (Cann - Siegfried, 1990). When individuals are high in the propensity to exhibit both task-oriented and interpersonally-oriented behaviour, they adopt (Hoffman - Borders, 2001) the profile of an androgynous leader, one who is high in both masculinity and femininity (Sargent, 1981). When individuals are low in the propensity to exhibit either type of behaviour and display laissez-faire leadership, however, they adopt (Bem, 1981) the profile of an undifferentiated leader, who is low in both masculinity and femininity.

In recent years, transformational and transactional leadership have become the primary focus of leadership theories ((Judge - Bono, 2000; Judge - Piccolo, 2004). The call for transformational leadership has occurred partly in recognition of the changing economic environment in which organisations operate. As global environments become more turbulent, highly competitive, and reliant on new technologies, they call for "high involvement" organisations with decentralized authority, flexible structures, and fewer managerial levels (Drucker, 1988; Lawler, 1995). Transformational leaders motivate subordinates to transcend their own self-interests for the good of the group or organisation by setting high standards for performance and then developing subordinates to achieve these standards (Bass - Avolio - Atwater, 1996; Rafferty - Griffin, 2004). Transformational leaders exhibit four types of behaviour (Powell, 2012): charisma, inspirational motivation, intellectual stimulation and individualized consideration.

Overall, the transformational leadership style appears to be more congruent with the feminine than with the masculine gender role (Bass - Avolio - Atwater, 1996; Judge - Bono, 2000; Kark, 2004; Vinkenburg Engen - Eagly - Johannesen-Schmidt, 2011). Transformational leadership is positively associated with nurturance and agreeableness, feminine traits, and negatively associated with aggression, a masculine trait. Individualized consideration is congruent with the feminine gender role because its developmental focus reflects a high concern with relationships and the needs of others.

Survey results revealed that woman use the transformational leadership style more. In general, women, more than men, use power based on charisma and contacts (personal power), as opposed to power based on organizational position, title, and the ability to reward and punish (structural power) (Rosener, 1990).

In contrast with the transformational leaders, transactional leaders focus on clarifying the responsibilities of subordinates and then responding to how well subordinates execute their responsibilities (Bass - Avolio - Atwater, 1996; Rafferty - Griffin, 2004). They exhibit two kinds of behaviour: contingent reward (by promising and providing suitable rewards if followers achieve their assigned objectives); and management by exception (by intervening to correct follower performance either in anticipation of a problem or after a problem has occurred). Transactional leaders who engage in active management by exception monitor subordinate performance for mistakes (Powell, 2012), whereas those who engage in passive management by exception wait for subordinate difficulties to be brought to their attention before intervening. Transformational leaders may be transactional when it is necessary to achieve their goals, however, transactional leaders are seldom transformational. Both active and passive management by exception seem compatible with the masculine gender role in their focus on correcting followers' mistakes, because they stress immediate task accomplishment over long-term building of relationships and favour the use of leadership position to control others. In addition, contingent reward appears to be consistent with the masculine gender role because it is primarily task-oriented.

Managers may also exhibit different decision-making styles. A leader who exhibits a democratic style 
of decision making allows subordinates to participate in decision making, whereas a leader who exhibits an autocratic style of decision making discourages such participation. These are generally considered to be opposite decision-making styles (Eagly et al., 1992). Tannenbaum and Schmidt's (1973) situational leadership theory recommends that managers become more democratic and less autocratic in decision making, as subordinates display a greater need for independence, readiness to assume responsibility, and ability to solve problems as a team. Linking styles to gender stereotypes, the autocratic style of decision making is associated more with the masculine stereotype, reflecting a greater emphasis on dominance and control over others (Eagly et al., 1992). In contrast, the democratic style of decision making is more associated with the feminine stereotype, reflecting a greater emphasis on the involvement of others.

As the main tendencies in business requires customer orientation, horizontal structures and team work increasingly requires co-operation, communication and interpersonal skills, i.e., the 'feminine' competencies became advantageous (Simpson - Ross-Smith - Lewis, 2008). Rather than a weakness to be overcome and 'solved', difference is seen as strength; as opposed to experiencing gender as a disadvantage, the special contribution approach indicates that 'femininity' is a newly recognized asset and holds potential advantage in the workplace.

Under current circumstances, individuals who are able to articulate and rally followers behind a unified vision, stimulate creativity in achieving the vision, and develop rewards, recognition, and career opportunities for high-performing specialists are best suited for leader roles in such organisations (Hitt - Harrison - Ireland - Best, 1998). Management approaches that emphasize open communication and delegation are most conducive to the rapid innovation and response to customers that organisations need to survive in such environments. As a result, successful organisations are shifting away from an authoritarian model of leadership and towards a more transformational and democratic model. In Western societies, management has been the last bastion of the autocratic style (Collins, 1997). However, consistent with the recent focus of leadership theories, fewer organisations are choosing this style (Drucker, 1988; Hitt et al., 1998; Lawler et al., 1995). This tendency underlines the growing importance of feminine stereotype characteristics (Powell, 2012).

Even though early leadership theories were developed at a time when there were far fewer women in leader roles, review of the major theories does not support that fact that leader stereotypes place a high value on masculine characteristics. At the same time, leader- ship theories do not exclusively endorse feminine characteristics either. Instead, situational leadership theories (Hersey et al., 2008; Tannenbaum - Schmidt, 1973) recommend that leaders vary the amount of masculine and feminine characteristics they display according to the situation. Thus, leadership theories do not suggest that either feminine or masculine behaviours are the single keys to leader effectiveness (Powell, 2012).

Altogether the 'feminization' thesis has been influential in shaping beliefs about possible changes in gender positioning in society and in organizations (Broadbridge - Simpson, 2011).

Some researchers, however, pointed out the potential danger of the stereotypical 'caring' leadership associated with women managers (Billing - Alvesson, 1997). A related issue is how 'femininity' and organizations influence and develop each other and whether organizational or feminist research has paid enough attention to this factor (Ely - Padavic, 2007). The authors call attention to the danger that repetition of sex difference findings that stem from an under-theorised body of research runs the risk of reifying differences - of making them seem natural. "If study after study reports findings that align with stereotypes and does not address why, then these differences - in temperament, values, attitudes, and behaviours - take on a determinative quality. This approach also precludes new ways of thinking about gender" (Ely - Padavic, 2007, p. 1122.).

Empirical results such as (Lückerath-Rovers, 2013) (see more in section 'Quantitative analyses: What would be the ideal composition?') support the notion that companies with women on their boards have a better connection with the relevant stakeholders at all levels of the company, which also improves the company's reputation. This follows from the resource dependency theory, which states the board of directors also serves as a linkage mechanism towards all relevant stakeholders (Pfeffer - Salancing, 1977; Hillman - Parthiban Bloom, 2007). Also (female) employees at companies with women on their boards are more motivated to excel because they all see that they can reach the top (Rose, 2007). Companies with women on their board could be more successful, because people are promoted on the basis of their capabilities and not on the basis of demographic characteristics (Krishnan - Park, 2005). These companies are more successful in making use of the whole talent pool for competent directors instead of only half of the talent pool.

\section{Alternative values (the upper right corner of the matrix, see Figure 1)}

In the matrix 'Alternative values' are located in the intersection of 'Ethical/political considerations (equality, 
humanisation of the workplace)' and gender differences. This means that those values are covered here that have stereotypically feminine nature. Unlike in the case of 'special contribution' the emphasis is put primarily not on economic efficiency, but more on ethics and humanization.

Humanisation of the workplace is advantageous for both women and men. Prominent in the content of gender stereotypes are two themes: the communal (e.g. sympathetic, concerned about others) qualities of women and the agentic (e.g. aggressive, decisive) qualities of men (Schein, 2004). Generally, the communal stereotype refers to an interpersonally sensitive orientation by which individuals are concerned with the welfare of others and with interpersonal relationships. Women are stereotypically viewed as kind, helpful, and empathic, as well as, motivated by needs for nurturance and affiliation. In contrast, the agentic stereotype refers to a self-interested, task focused orientation where individuals are concerned with mastery, dominance, and control. Men are stereotypically viewed as ambitious, competent, competitive, and individualistic, as well as, motivated by needs for autonomy, aggression, dominance, achievement, and endurance. In addition, gender stereotypes encompass other themes having to do with, for example, cognitive abilities and physical characteristics As the norms are set by the agentic values, other 'feminine' characteristics such as friendly atmosphere (Wicks - Bradshaw, 1999), emphasising peer cohesion, or being cooperative and valuing and developing people (Phalen, 2000) cannot prevail.

Women are supposed to be more risk averse than men (e.g., Jianakoplos - Bernasek, 1998; Niederle Vesterlund, 2007; Croson - Gneezy, 2009). Although there are some debates, it is well documented in the literature that men and women in the boardrooms differ in a whole range of respects (Joecks - Pull -Vetter, 2012): women tend to be less aggressive in their choice of strategy and more likely to invest in a sustainable way (Ertac - Gurdal, 2012; Charness - Gneezy, 2012).

The notion that female directors help create shareholder value through their influence on acquisition decisions is well exemplified and supported by a research (Maurice Levi, 2014) on mergers and acquisition. The less overconfident female directors are, the less they overestimate merger gains. As a result, firms with female directors are less likely to make acquisitions and if they do, pay lower bid premia.

Research finds that states with more women involved in government are also less prone to corruption (Dollar - Fisman - Gatti, 2001; Swami et al., 2001). Behavioural studies have found women to be more trust-worthy and public-spirited than men. These results suggest that women the "fairer sex" should be particularly effective in promoting honest government. Other research sug- gests (Sung, 82) that the observed association between gender and corruption is spurious and mainly caused by its context, liberal democracy - a political system that promotes gender equality and better governance. Data support this "fairer system" thesis.

Other research (Wangnerud, 2014) presents evidence from 18 European countries showing that where levels of corruption are high, the proportion of women elected is low. It may be a consequence of the fact that corruption indicates the presence of 'shadowy arrangements' that benefit the already privileged and pose a direct obstacle to women when male-dominated networks influence political parties' candidate selection.

A recent review of experimental evidence (Esarey, 2014) indicates that women are not necessarily more honest or averse to corruption than men in either the laboratory or the field (Frank - Lambsdorff - Boehm, 2011). Rather, the attitudes and behaviours of women concerning corruption depend on institutional and cultural contexts in these experimental situations (Alatas, 2009; Alhassan-Alolo, 2007). The authors argue that a great deal of experimental and observational evidence has shown women to be more risk-averse than men when confronting identical situations. In democratic regimes, where corruption is typically stigmatized by law and custom, corruption is a risky behaviour. Ergo, we should generally expect women to engage less in corrupt behaviour in democracies. We should also expect variations in these governments' ability or desire to hold corrupt officials accountable to have a greater effect on women, and therefore to be reflected in variations in the inverse link between gender and corruption. The strongest relationship between gender and corruption should be where accountability is strongest.

\section{Quantitative analyses: What would be the ideal composition?}

The empirical evidence on the link between female representation on the board and firm performance is controversial. While some studies found positive correlation between women on boards and firm performance (Carter - D'Souza - Simkins - Simpson, 2010; Carter, 2011; Barta - Kleiner - Neumann, 2012), others provided negative links (Gallego-Álvarez - García-Sanchez - Rodríguez-Dominguez, 2009; Holst - Kirsch, 2014), while still others did not find any interdependence whatsoever between the two (Haslam - Ryan - Kulich - Trojanowski - Atkins, 2010).

There are a number of factors that complicate such studies. First, there is the time component (it takes time for board members to become sufficiently knowledgeable and experienced in board matters to be able to influence decisions and have impact on the organization). 
Other important components are the individuals' age, experience or the relationship with the other members of the board. For example, an analysis of German banks' executive boards in the period from 1994 to 2010 at first sight showed that a higher proportion of women on the executive board resulted in a riskier business model. After a closer look, however, it became clear that "... decreases in average board age robustly increase banks' portfolio risk. This effect is statistically and also economically large" (Berger, 2013). This means that the explanatory factor was not female participation, but rather the decrease in the board members' average age, male and female alike.

Some of the differences in the studies' results may be due to the data being obtained from different countries (with differing board systems) and in different time periods, as well as, from the use of different performance measures and estimation methods (Campbell - Mínguez-Vera - 2008, p. 441.; Rhode - Packel, 2010). The Glass cliff effect (see in section Equal chances) may also distort some data.

Results may further be affected by studies being compared with differing ratios of women on boards (Joecks - Pull - Vetter, 2012). If we assume that the link between gender diversity and performance were non-linear and, e.g., U-shaped, in case of boards with few women, the relation between gender diversity and performance would be negative, while in a reverse case it would be positive.

This U shape assumption is built on Kanter's influential work (1977a, p. 206-242.) and (1977b) concerning gender diversity in groups i.e., the critical mass theory, in which Kanter provides insight into effectiveness and gender composition. In her analysis of group interaction processes, Kanter sets up four different categories of groups according to their composition: uniform groups, skewed groups, tilted groups, and balanced groups:

- Uniform groups are groups in which all members share the same (visible) characteristic. With reference to salient external master statuses like gender, its members are similar.

- Skewed groups (up to $20 \%$ women) are groups in which one dominant type controls the few, thus controlling the group and its culture. The few are called "tokens." Kanter highlighted the problems faced by women in groups containing a large preponderance of men over women (the rare "token managers"): how men assigned to women based their opinion on stereotypical attributes and, through informal networking and other processes, 'closed ranks' against them.

- Tilted groups (20-40\%) are groups with a less extreme distribution. Unlike in skewed groups, mi- nority members can ally and influence the culture of the group. Members are to be differentiated from each other based on their skills and abilities. In a so-called balanced group, majority and minority turn into potential subgroups where gender-based differences become less and less important.

As regards group interaction processes, Kanter regards skewed groups to be especially problematic. Either the tokens are in the focus or they are overlooked, and they may be subject to stereotyping (1977a). For women, there are different strategies to cope with a token status (1977b). Either they pretend that differences between women and men do not exist, or they hide their individual characteristics behind stereotypes. The incumbent men, too, will also behave differently in skewed as opposed to uniform groups, leading skewed groups to be outperformed by uniform ones.

With an increase in their relative numbers from a skewed to a tilted or even a balanced group, women are more likely to be individually differentiated from each other. As a result, they might then bring in their different knowledge bases and perspectives. Although women in the boardrooms are individuals and may be different from the gender stereotypes, there is a good chance that they may add value to a male-dominated boardroom by providing new perspectives and by asking different questions (Burke, 1997; Burgess - Tharenou, 2002; Farrell - Hersch, 2005; Konrad - Kramer, 2006; Apesteguia et al., 2012).

To sum up: the critical mass theory postulates that until a certain threshold or 'critical mass' of women in a group is reached, the focus of the group members is not on the different abilities and skills that women bring into the group. In consequence, skewed groups will have lower performance than uniform or tilted and balanced groups, while tilted groups will outperform uniform and skewed groups (Konrad - Kramer - Erkut, 2008; Torcia - Calabro - Huse, 2011; Joecks - Pull Vetter, 2012).

Several empirical evidences support the critical mass theory. In their qualitative research, Konrad, and Kramer (2006) found that a clear shift in culture occurs when boards have three or more women. At that critical mass, their research shows, women tend to be regarded by other board members not as "female directors' but simply as directors, and they don't report being isolates or ignored. In a later study, the following advantages were identified (Konrad - Kramer - Erkut, 2008, p. 146.): 'First, multiple women help to break the stereotypes that solo women are subjected to. Second, a critical mass of women helps to change an all-male communication dynamic. Third and last, research on influence and conformity in groups indicates that three 
may be somewhat of a "magic number" in group dynamics'. Results of Torchia, Calabro and Huse (2011) suggest that attaining critical mass - going from one or two women (a few tokens) to at least three women (consistent minority) - makes enhancement of the level of firm innovation possible. Joecks and Vetter (2012) found that skewed supervisory boards were outperformed by tilted supervisory boards.

One of the most cited studies, prepared by Catalyst (2011), highlights similar tendencies: companies with the highest female board membership quartile had an average of $16 \%$ higher return on sales (ROS) than those in the lowest quartile and their advantage in terms of return on invested capital (ROIC) was $26 \%$. Companies of at least three women board members who worked at least for four years outperformed the others by $84 \%$ and $60 \%$, respectively in terms of ROS and ROIC, and $46 \%$ in terms of return on equity (ROE). The critical mass theory was proved to be true in the Chinese private, stock exchange listed companies. (Liu, 2014). Statistics show that female executive directors have a stronger positive effect on firm performance than female non-executive directors, indicating that the executive effect outweighs the monitoring effect. A Dutch study (Lückerath-Rovers, 2013) shows that firms with women directors perform better than the others. The author calls attention to the fact that having women on the board is a logical consequence of a more innovative, modern, and transparent enterprise where all levels of the company achieve high performance (Singh - Vinnicombe, 2004).

Naturally, women directors are considered to be an inhomogeneous group (Joecks - Pull - Vetter, 2012). Each woman is unique with different values and characteristics to the rest of the sub-group (Huse et al., 2009; Nielsen - Huse, 2010). This is in line with (Mansbridge, 2005), who attaches a caveat to the idea of essentialism inherent in gender quotas. Indeed, gender essentialism - the idea that all women possess some sort of shared characteristics simply because they are women - is too-frequently a side effect of the efforts to achieve equal representation of women. Essentialist understandings of gender are dangerous not only because they mask diversity among women, but also because they treat gender identity as rigid and defined by a limited set of characteristics. In exaggerating differences between males and females, the less powerful female group is often seen as more homogeneous.

Boardbridge - Simpson worried (2011) about the current conceptualizations that gender issues have been 'solved' with a tendency towards 'gender denial' in understandings of work based disadvantage. They concluded that there was still a need to continue to monitor and publicize gender differences, and clarify and con- ceptualize emerging gendered hierarchies, as well as, reveal hidden, gendered practices.

We still should not forget the fact that even under the circumstances of a global race for management talent, female representation on the corporate boards is below 15 per cent, which means a lot waste of talent and creative energy. Indeed, there is an essential difference between the two genders that is disadvantageous for women in moving up the career ladder. A number of components of this difference is constructed by the fact that when we do business we do gender as well. The inner ambiguity of gender construction is expressed in the dilemma: how can we do gender (Gherardi, 1994) without second-sexing the female?

\section{Exposing meritocracy (the lower left corner of the matrix, see Table 1)}

Although a number of arguments supporting female participation in leadership were presented, in reality female participation in senior management is still low (Figure 1). In sections 6 and 7 I summarize the findings of research documents that investigated the reasons for this underrepresentation.

When searching for the causes of low female representation, studying gender symbols and metaphors makes it possible to use indirect speech and, discursively, to change gender relationships within organizations. Metaphors are often used for explaining certain aspects of cultures, because they represent 'conceptual windows which help the organizational analyst gain better access to rich avenues of meaning' (Chia, 1996, p. 128.).

The metaphor of 'glass ceiling' has been widely used since the late eighties (Morrison - White - Velsor, 1987; Billing, 1997; Powell G. N., 1999; Liff - Ward, 2001). According to Murrell and Hayes James (2001, p. 244.): "most well-known illustrations of discrimination in the workplace are captured by the concept of 'glass ceiling', which defines the invisible barrier that prevents many women and minorities from advancing into senior and executive management positions within organizations." The reason for the name 'glass' is that no visible constrains may be identified, because the legal system provides equal opportunities and no open discrimination is applied.

Researchers later suggested that some new characteristics and the complexity of the issue could better be reflected by the metaphor of 'labyrinth' (Eagly - Carli, 2007). As 'times have changed ... the glass ceiling metaphor is now more wrong than right' for two reasons (p. 64.). On the one hand, positive changes made the term outdated, because of the description of an absolute barrier at a specific high level within organizations that has changed. Also, as a result of some recent devel- 
opments, female chief executives and board members were appointed, i.e.: they managed to break the glass. On the other hand, the metaphor implies that women and men have equal access to good entry- and midlevel positions and actually they do not. The new metaphor 'labyrinth' expresses the never-ending challenges that women traverse to attain and effectively exercise power and authority in the hierarchical organizations.

Survey results (Carter - Silva, 2010) revealed that even in those companies that implemented programs to fix structural biases against women and support their full participation in leadership, women continue to lag behind men at every single career stage. The management pipeline is not healthy; inequality remains entrenched. Even after adjusting for the years of work experience, industry, and region, it was found that men started their careers at higher levels than women. The finding held when only those women and men were included who said they were aiming for senior executive positions. Even amongst women and men without children, living at home, men still started at higher levels. It was also revealed that after starting out "behind", women didn't catch up. Men move further up the career ladder - and they move faster. Another research showed (Ibarra - Carter - Sylva, 2010) that differences could be recognized in favour of men even in the context of mentoring programs.

The fact that 'ceilings' can be found at every level of the hierarchy inspired the construction of the 'leaky pipeline' metaphor (Carter - Silva, 2010) and supported the 'labyrinth' metaphor, as well. Finally, the metaphor of 'glass firewall' portrays a sort of discrimination that is complex, fluid, incoherent, and heterogeneous, and stresses a processual view of discrimination as 'doing discrimination' (Bendl - Schmidt, 2010, p. 629.).

"Notions of meritocracy, based on supposedly objective criteria of education, experience and skills, have strong purchase in understandings and applications of 'fairness' at work - suggesting that women can compete for jobs and promotion on the "same basis' as men" (Broadbridge - Simpson, 2011, p. 477.). These 'neutral' criteria on which meritocracy are based, however, do contain a gender bias (Lewis - Simpson, 2010).

The societal and cultural aspects of gender may help find the key to the challenge in meritocracy. As Billing and Alvesson explain (1997), the traditional gendered division of labour, i.e. men specialising in paid employment and women specialising in unpaid family work, has long been the societal norm. As a result, the public and the private spaces have become separate. The public sphere, with its bureaucratic organisations, is historically dominated by men. The corporate world - and especially top management circles - can thus be compared to a game that was invented by and for male players, which follows certain rules that correspond to men's ideas and principles of work. Other authors support this idea with the reasoning that organisational cultures are often conceptualised as being more 'masculine' or 'male', indicating that they are more in line with stereotypical masculine values such as aggressiveness, competition, status-orientation, hierarchy and control (Wajcman, 1998). Historically most organisations have been founded by and are still dominated by men, especially in the higher management ranks (Terjesen Singh, 2008). As a result, organisational cultures have been created which, intentionally or not, consider male preferences and life patterns as the norm and which value male attributes more than female ones (Meyerson, 2000). Due to socialization and family-related expectations, women may be limited in gaining the same level of experiences and skills as men. At the same time, men may be more oriented towards ambition and career due to the traditional roles of the two genders (Bagihole Goode, 2001).

As social acceptance and personal trust are also important and men have more access to male networks where the powerful decision-makers belong to, thus, in this respect, merit does not translate the same way for the two genders. This supports Wajcman's (1998) notion of 'contemporary patriarchy', i.e. the subordination of women within a framework of equality. Modern practices of mentoring sponsoring and other personal development activities, however, may counterbalance such disadvantages if applied in the context of true meritocracy (Carter - Silva, 2010).

An example for masculine merits is the male-biased definition of commitment (Schein, 2004). Even at the time of PC-s, laptops, internet and smart phones, which provide a great deal of flexibility in work, the widespread assumption is that a committed manager is always available, accepts unpredictable working hours, works late into the evening and over weekends in the office, and shows a high degree of spontaneity and flexibility. This creates specific challenges for women who are often unable to conform to this norm due to the traditional family-related responsibilities. The work-life balance debate (Tóth, 2005) shows that that the existence of such a long hour's norm, along with high demands in terms of flexibility and geographical mobility, creates working conditions that are incompatible with most women's lives. Nobody challenges this norm even if with better planning work could be managed differently, but with the same efficiency.

Even if a woman could accept the above conditions she may not even been asked due to the presumptions. A survey (McKinsey \& Company, 2012) revealed cases where women applicants were rejected because of the 24/7 availability requirement; however, nobody 
checked whether they would have been able to meet the requirement or considered whether unlimited availability was really necessary.

Assumed neutrality may lead to situations that Simpson, Ross-Smith and Lewis (2008) revealed: women managers rationalized observed disadvantage as the effects of personal decisions, thus avoiding reference to gendered organizational practice that worked against them. Meritocracy is a good excuse for low female representation in senior positions. An example for this is (Simpson - Ross-Smith - Lewis, p. 199-200.) that male senior managers and CEOs make frequent references to meritocratic principles in their hiring and promotion decisions to demonstrate their adherence and commitment to gender equality in their organizations.

\section{Barriers to equal opportunities (the upper left corner of the matrix, see Figure 1)}

A number of review articles such as (Ely - Padavic, 2007; Terjesen - Sealy - Sing, 2009; Broadbridge - Simpson, 2011; Powell, 2012; Danowitz - Hanappi-Egger, 2012; Kornau - Festing, 2013) discuss research outcomes on components of unequal opportunities of women to reach senior positions. Most of the research results suggest that the playing field that constitutes the managerial ranks continues to be tilted in favour of men and behaviours associated with the masculine gender stereotype, a phenomenon that occurs despite what leadership theories and field evidence would suggest.

One of the most important factors is that even if the beliefs about the personal characteristics of a successful middle-manager have changed over time, men are still believed to be better managers and better managers are still believed to be masculine. A similar pattern of results is exhibited in countries with very different national cultures such as the UK, Germany, Japan, China, Turkey, Sweden, and South Africa. In these countries both men and women believe that men are more similar to successful managers than women are, but men endorse such beliefs to a greater extent than women do (Schein - Mueller, 1992; Schein et al., 1996; Schein, 2001; Vicsek, 2002; Fullagar et al., 2003; Booysen Nkomo, 2010).

These results suggest that international beliefs about managers are best expressed as think manager - think male, especially among men (Powell - Butterfield, 1989, 2003; Koenig - Eagly - Mitchell - Ristikari, 2011). The fact that a very high proportion of women top managers are daughters of top-manager fathers (Nagy, 2001) is in line with this belief. This model seems capable of a 'cross-effect' and facilitates the formation of self-confidence and role-model necessary for attaining the posi- tion. A related finding (Alvesson - Billing, 1977) is that a high proportion of women managers identify with their fathers rather than their mothers.

One of theories to explain the phenomenon is the lack of fit model (Heilman, 1983, 1995, 2001; Haslam - Ryan, 2008). It suggests that even in cases when the female and male managers being evaluated are exhibiting exactly the same behaviour, individuals who believe that men possess the characteristics that are best suited for the managerial role more than women are likely to evaluate male managers more favourably than female ones.

Another aspect of this issue is highlighted by the role congruity theory where leader and gender stereotypes put female leaders at a distinct disadvantage by forcing them to deal with the perceived incongruity between the leader role and their gender role (Eagly - Karau, 2002). Gender role congruence is defined as "the extent to which leaders behave in a manner that is congruent with gender role expectations" (Eagly et al., 1992, p. 5.). If women compete with men for leadership positions and conform to the leader role, they fail to meet the requirements of the female gender role, which calls for feminine niceness and deference to the authority of men (Rudman - Glick, 2001). At the same time, if women conform to the female gender role, they fail to meet the requirements of the leader role.

The status characteristics theory (Webster - Berger, 2006; Ridgeway, 1991, 2009) provides a possible explanation on the background of these phenomena. The theory argues that unequal societal status is assigned to the sexes, with men granted higher status than women (Nagy - Vicsek, 2008). Because of their stronger status position, men get more opportunities to initiate actions and influence decision-making, leading them to specialize in task-oriented traits. In contrast, due to their weaker status position, women are required to monitor others' reactions to themselves and be responsive to interpersonal cues, leading them to specialize in interpersonally-oriented traits (Aries, 2006).

Sayers calls the attention to the fact that the gender wage gap is partly a result of these negative attitudes towards women indicating that broader societal expectations cause people to unconsciously believe that female work is of less value (Sayers, 2012).

According to the similarity-attraction paradigm, people make the most positive evaluations of and decisions about those whom they see as being similar to themselves (Byrne - Neuman, 1992). Kanter (1977a) characterized the results of such a preference in management ranks as "homosocial reproduction." Uncertainty is always present when individuals are relied upon, and the effects of such uncertainty are greatest when the individual holds significant responsibility for 
the direction of the organisation. One way to minimize uncertainty in the executive suite is to close top management positions to people who are regarded as "different".

There is one exception, the 'glass cliff'. Despite women's difficulties in obtaining demanding assignments, other evidence shows that some women are placed, more often than comparable men, in highly risky positions (Haslam - Ryan, 2008; Bruckmüller - Branscombe, 2010). When companies are facing financial downturns and declining performance, executives have a fairly high risk of failure. Companies may be more willing to have female executives take these risks, and women may be more willing to accept such positions, given their lesser prospects for obtaining more desirable positions, or their lack of access to networks that might steer them away from such jobs. Some other research also revealed (Haslam - Ryan - Kulich - Trojanowski - Atkins, 2010) that in some cases, stock-market performance reflected the perception of organizational crisis at the time of women's appointment to leadership positions regardless of the real performance of companies. The latter finding is supported by some further empirical results (Torcia Calabro - Huse, 2011).

Women senior managers in skewed groups are not perceived as individuals and have to cope with a number of psychological challenges as a minority below the critical mass (see further details in section 'Quantitative analyses: What would be the ideal composition?').

Devaluation of women and related activities happens when abilities such as communication, empathy, caring that are stereotyped as 'women skills' are not considered necessary for line management, therefore women rarely have opportunities to receive such mid-manager jobs where they can practice and prove their abilities. Men encounter broader-based tasks much more frequently during their work (Eagly - Carli, 2007). They have to carry out pre-committed, quantified plans under time pressure and resource limitations, while constantly receiving criticism, which they have to learn how to handle (Bálint, 2007). Vertical segregation (Eagly Carli, 2007; Nagy, 2007; Nagy - Primecz, 2010) means that women are typically taken into middle-management positions only in support functions such as HR, PR, marketing, accounting and finance, i.e. behind the 'glass wall'. These areas also demand performance, but in a different way from the areas dominated by men, and so women get stuck in these functions, because there is rarely a route upwards. They have no occasion (Nagy, 2007) to learn the routines and develop the skills that render them capable of taking on a full-scale top management position. The positions are thus filled by men. Internal units operating as profit centres are still mostly bastions of the male empire.
Men's negative attitude towards women executives partly comes from the fact that they identify these women as their competitors (Everett - Thorne - Danehower, 1996), which means, in effect, that they do not like to perceive more competitors than previously, when only other men represented a potential 'danger' to them.

A further disadvantage for women is the exclusion from male networks. Both sexes often form social networks dominated by their own sex, and women often experience exclusion from informal "old boys' networks" (e.g. Katila - Meriläinen, 1999; Miller, 2002; Zahidi - Ibarra, 2010; Featherstone, 2004). Segregated networks are not optimal for women's advancement, because networks populated by men are generally more powerful. One way to overcome this limitation is to develop mentoring relationships, which provide one way of gaining social capital and tend to enhance the individuals' career progress (Allen, 2004). Mentors who hold powerful positions are able to offer considerable career facilitation. Yet, mentoring relationships, too, in a number of cases tend to form along same-sex lines.

Due to the pervasiveness of stereotypical competition and aggressiveness, women in highly masculine domains often have to contend with criticisms that they lack the toughness and competitiveness needed to succeed. In such settings, it is difficult for women to build relationships and gain acceptance in influential networks (Timberlake, 2005).

Lack of female support is due to the very low representation of women in CEO and executive director positions. This leads to the lack of female mentors and role models. We have already concluded that there are even less women who have managed career and family issues successfully (Liff - Ward, 2001; Nagy, 2001). Women can experience gains from relationships with other women, especially in terms of social support, role modelling, and information about overcoming discrimination (Bilimoria, 2006; Dougherty - Forret, 2004; Timberlake, 2005). At the same time there is also the 'Queen Bee Syndrome' (Mavin, 2008) which occurs when a female senior executive - enjoying the unique position of being the only woman visible - is unwilling to support younger women. Many senior executive women do not wish to be perceived primarily as representatives of the female gender group, but rather as competent leaders, and are thus not prepared to act as visible change agents to increase the representation of women in higher hierarchical levels.

Hierarchical structures play a role because - partly due to the socialization - more men favour power and authority than women (Schwartz - Rubel-Lifschitz, 2009; Adams - Funk, 2012). Female respondents argue that organisational culture should be less accepting of established authority (Wicks - Bradshaw, 1999) and, 
instead, more participatory (van Vianen - Fisher, 2002; McTavish - Miller, 2009). It was also found that organisational practices that emphasise low power distance (House - Javidan - Hagnes - Dorfman, 2002) are correlated positively to the proportion of women in leadership positions (Bajdo - Dickson, 2001).

Women may be irritated by a highly competitive approach to business (Miller, 2002), as well as by aggressive competition at peer level. This is accompanied by political power games and involves, for instance, project rivalry and ownership claims (Simpson, 2000). Evidence also suggests that women are uncomfortable with men's management styles, as they consider them to be too aggressive and focused on status and visibility (Rutherford, 2001). Based on in-group/out-group categorisation processes, it is not surprising to find that men hold negative attitudes towards female executives with whom they have to compete and do not consider them as equally suited for management jobs (Everett Thorne - Danehower, 1996).

Sexism in daily interactions may be experienced when leader roles' perceptions are extremely masculine and people suspect that a woman is not qualified for the position; this often results in resistance to the woman's authority (Eagly - Karau, 2002) and (Eagly - Carli, 2007). In a dominantly male environment, women often experience sexist or hostile jokes (Simpson, 2000). In its more subtle forms, negative male attitudes are revealed by ignoring women in meetings, not taking them seriously or playing power games at their expense (Phalen, 2000).

A study (Tienari, 2013) suggests that executive search consultants are generally aware of the exclusion of women in their assignments, although, they underline their limited latitude in including more women in search processes. If there is no explicit request for women candidates, headhunters - under time pressure - are not willing to extend the search outside their established network of contacts. Profiling (Mathieu, 2009) is another example for exclusion as the requirement may suggest male candidates only.

Differences between women and men may be more pronounced when women are in a position of lower access to power than their male colleagues. The good news for women is that these less masculine ways of leading have gained cultural currency as the traditionally masculine command-and-control style has become less admired than previously. This shift reflects the greater complexity of modern organizations. Evidence increasingly suggests that women tend to be better suited than men to serve as leaders in the ways required in the global economy (Powell, 2012). An appropriate manager of our time gains less from ordering others about and more from assembling a team of smart, moti- vated subordinates who together figure out how to solve problems (Eagly - Carli, 2007).

In light of the debates on gender quota, the question of whether organisations should choose women for leader roles on the basis of their sex is a very relevant one. The challenge for organisations is to take advantage of and develop the capabilities of all individuals in leader roles and then create conditions that give leaders of both sexes true equal chances to succeed (Falkenberg, 1990; Yoder, 2001). To achieve this situation, hidden inequalities in chances and gender biased values in selection should be carefully considered. The goal should be to enhance the likelihood that all people, women and men, alike, will be effective in leader roles.

\section{Conclusions}

What does all the above tell us about women and men in senior management? Situational leadership theory suggests that leadership style should follow the nature of the situation, varying the amount of feminine and masculine features (Tannenbaum - Schmidt, 1973). Characteristics, that play key roles in good leadership and manager performance as their followers gain independence, responsibility and the ability to work well as a team, however, are more associated with female than male stereotypes (Blachard - Hersey - Johnson, 2000). In other words interpersonally orientated behaviours that use sophisticated motivation and aim satisfaction of subordinates have proven to be more efficient than task oriented approach with goal setting and initiating and checking activities (Cann - Siegfried, 1990) .

In contrast with autocratic style that is associated with masculine stereotype, democratic decision making is more associated with the feminine stereotype and fits better to the fast-changing, complex and global world. Transformational leadership style appears to be more congruent with the feminine than the masculine gender role, as it is positively associated with agreeableness and negatively with aggression (Bass - Avolio - Atwater, 1996).

Although quantitative analyses resulted in different outcomes partly due to different approaches, a number of studies found positive correlation between women representation on boards and firm performance (Carter - D'Souza - Simkins - Simpson, 2010; Carter, 2011; Barta - Kleiner - Neumann, 2012). Results may further be affected by studies being compared with differing ratios of women on boards (Joecks - Pull - Vetter, 2012). If we assume that the link between gender diversity and performance were non-linear and, e.g., U-shaped, in case of boards with few women, the relation between gender diversity and performance would be negative, while in a reverse case it would be positive. 
According to the critical mass theory the advantage of gender diversity in senior management teams is the highest where the representation of the minority group exceeds 30 per cent (Kanter, 1977b).

At the same time recent empirical facts show that women accounted for only three percent of CEOs and 13 percent of senior executives in Europe's stock exchange listed blue chip companies (Figure 1).

Key reasons why reality falls so far from the theoretical optimum are issues of deficiencies in the application of meritocracy and the lack of equal opportunities. A number of review articles such as (Ely - Padavic, 2007; Terjesen - Sealy - Sing, 2009; Broadbridge - Simpson, 2011; Danowitz - Hanappi-Egger, 2012; Kornau - Festing, 2013) discuss research outcomes on components of unequal opportunities of women to reach senior positions. Most of the research results suggest that the playing field that constitutes the managerial ranks continues to be tilted in favour of men and behaviours associated with the masculine gender stereotype (Powell, 2012).

Several measures have been made to increase female participation in senior management including equal treatment legislation, gender mainstreaming (integration of the gender perspective into all other policies) and specific measures for the advancement of women including recommendations and quota system in some countries (European Comission, 2016). A number of companies have introduced internal programs such as sensitivity trainings for men, career development trainings for women and mentoring schemes (Allen, 2004; Carter - Silva, 2010). The business sector, civil organizations, politicians and international organizations are making efforts to improve the situation.

As a number of obstacles are deeply rooted in culture and socialization (Alvesson - Billing, 1997; Wajcman, 1998; Heilman, 1983, 1995, 2001; Powell - Butterfield, 1989; Bagihole - Goode, 2001; Bajdo - Dickson, 2001; Nagy, 2001; Vicsek, 2002; Schein, 2004; Eagly - Carli, 2007; Terjesen - Singh, 2008; Haslam - Ryan, 2008; Schwartz - Rubel-Lifschitz, 2009; Adams - Funk, 2012) the changes are still slow. The causes are multiple, complex, and call for a comprehensive approach to tackle the problem. They stem from traditional gender roles and stereotypes, the lack of support for women and men to balance care responsibilities with work and the prevalent political and corporate cultures, to name just a few.

In order to improve the sophistication of different measures further research is needed. One issue is to find the way to achieve mutual respect and appreciation. It is proposed that senior men and women be interviewed to understand their perceptions, attitudes, feelings and beliefs about their roles and the ways of co-operation. Research conducted in the investor com- munity could be also useful as most of them do not appear to be concerned by gender diversity in the firms' senior management teams; the reasons for this have yet to be explored sufficiently. The effects of the measures introduced by governments are also worthy of study: which management positions are filled by women, what management styles are applied by those women and what are the experiences of the other members of the management teams.

\section{References}

Adams, R. - Funk, P. (2012): Beyond the glass ceiling: Does gender matter? Management Science: p. 219235.

Alatas, C. a. (2009): Gender, Culture, and Corruption: Insights from an Experimental Analysis. Southern Economic Journal: p. 663-680.

Alhassan-Alolo (2007): Fighting Public Sector Corruption in Ghana: Does Gender Matter? in: S. Bracking (2007): Corruption and Development. New York: Palgrave Macmillan: p. 205-221.

Allen, E. P. (2004): Career Benefits Associated With Mentoring for Proteges: A Meta-Analysis. Journal of Applied Psychology: p. 127-136.

Alvesson, M. - Billing, Y. D. (1997): Understanding Gender and Organization. Thousand Oaks: Sage

Alvesson, M. - Billing, Y. D. (1977): Understanding Gender and Organization. Thousand Oaks: Sage Publication

Apesteguia et al. (2012): The Impact of Gender Composition on Team Performance and Decision Making: Evidence from the Field. Management Science: p. 78-93.

Archer - Lloyd (2002): Sex and Gender. Cambridge: Cambridge University Press

Aries (2006): Sex Differences in Interaction: a Reexamination. in: K. Dindia (ed.): Sex Differences and Similarities in Communication (pp. 21-36). Mahwah, NJ: Erlbaum: p. 21-36.

Bagihole - Goode (2001): The contradiction of the myth of individual merit, and the reality of a patriarchal support system in academic careers; a feminist investigation. European Journal of Women's Studies: p. 161-180.

Bajdo - Dickson (2001): Perception of Organizational Culture and Women's Advancement in Organizations: A Cross-Cultural Examination. Sex Roles: p. 399-414.

Bálint, Z. (2007): Esélyegyenlőség és az üvegplafon vizsgálata női és férfi vezetők körében a gazdasági szférában Magyarországon. in: B. N. (ed.): Szervezet, menedzsment és nemek. Budapest: Aula: p. 104. 
Barta - Kleiner - Neumann (2012): Is there a payoff from top-team diversity?

Bass, B. M. - Avolio, B. J. - Atwater, L. (1996): The Transformational and Transactional Leadership of Men and Women. Applied Psychology: p. 5-34.

Bem, S. (1981): Bem Sex-Role Inventory: Professional Manual. Consulting Psychologists Press

Bendl, R. - Schmidt, A. (2010): From Glass Ceilings to Firewalls - Different Methaphors for Describing Discrimination. Gender, Work and Organization, 17(5): p. 612-634.

Berger, T. K. (2013): Executive board composition and bank risk taking. Journal of Corporate Finance

Bilimoria, D. (2006): The relationship between women corporate directors and women corporate officers. Journal of Business Ethics

Billing, Y. D. - Alvesson, M. (1997). Questioning the notion of feminin leadership: a critical perspective on the gender labelling leadership. in: Gender, Work and Organization: p. 144-157.

Blanchard, K. H. - Hersey, P. - Johnson, D. E. (2000): Leadership: Situational Approaches. in: H. J. Blachard (2000): Management of Organizational Behaviour. Harlow: Pearson: p. 94-113.

Booysen - Nkomo (2010): Gender role stereotypes and requisite management characteristics: The case of South Africa. Gender in Management: An International Journal: p. 285-300.

Broadbridge, A. - Hearn, J. (2008): Gender and management: New directions in research and continuing patterns in practice. British Journal of Management: p. 38-49.

Broadbridge, A. - Simpson, R. (2011): 25 Years On: Reflecting on the Past and Looking to the Future in Gender and Management Research. British Journal of Management: p. 470-483.

Bruckmüller - Branscombe (2010): The glass cliff: When and why women are selected as leaders in crisis contexts. British Journal of Social Psychology: p. 433-451.

Burgess - Tharenou (2002): Women Board Directors: Characteristics of the Few. Journal of Business Ethics: p. 39-49.

Burke, R. (1997): Women on corporate boards of directors: A needed resource. in: R. B. (ed.): Women in Corporate Management. Kluwer Academic Publishers: p. 37-43.

Butterfield - Powell (2003): Gender, gender identity, and aspirations to top management. Women in Management Review: p. 88-96.

Byrne - Neuman (1992): The implications of attraction research for organizational issues. in: K. Kelley (1992): Issues, Theory and Research in Industrial/ Organizational Psychology). New York, NY: Elsevier Sciences: p. 29-70.
Calás, M. - Smircich, L. (1996): From the 'Women's' Point of View: Feminist Approaches of Organizational Studies. in: Clegg - Hardy - Nord (1996): Handbook of Organization Studies. Thousand Oaks: Sage: p. 218-258.

Campbell - Mínguez-Vera (2008): Gender Diversity in the Boardroom and Firm Financial Performance. Journal of Business Ethics: p. 435-481.

Cann, A. - Siegfried, W. (1990): Gender stereotypes and dimensions of effective leader behaviour. Sex Roles: p. 413-419.

Carter, D. A. - D'Souza, F. - Simkins, B. J. - Simpson, W. G. (2010): The Gender and Ethnic Diversity of US Boards and Board Committees and Firm Financial Performance. Corporate Governance: An International Review: p. 396-414.

Carter, N. M. (2011 ): The Bottom Line: Corporate Performance and Women's Representation on Boards (2004-2008). Catalyst

Carter, N. M. - Silva, C. (2010): Women in Management: Delusions of Progress. Harvard Business Review, March

Catalyst (2011): Performance and Women's Representation on Boards (2004-2008)

Charness - Gneezy (2012): Strong Evidence for Gender Differences in Risk Taking. Journal of Economic Behavior \& Organization: p. 50-58.

Chia, R. (1996): Organizational analysis as deconstructive practice. Berlin: de Gruiter

Croson - Gneezy (2009): Gender Differences in Preferences. Journal of Economic Literature: p. 448-474.

Danowitz - Hanappi-Egger (2012): Diversity as Strategy. in: Danowitz - Hanappi-Egger - Mensi-Klarbach - Danowitz (eds.): Diversity in Organizations: Concepts and Practices (Vol. Diversity in organizations : Concepts and practices). London: Palgrave Macmillan: p. 137-158.

Dollar - Fisman - Gatti (2001): Are women really the "fairer" sex? Corruption and women in government. Journal of Economic Behavior \& Organization: p. 423-429.

Dougherty - Forret (2004): Networking behaviors and career outcomes. Journal Of Organizational Behavior: p. 419-437.

Drucker, P. F. (1988): The Coming of the New Organization. Harvard Business Review: p. 1-11.

Eagly, A. H. et al. (1992): Gender and leadership style: a meta-analysis. Psychological Bulletin: p. 3-22.

Eagly, A. H. - Karau (2002): Role congruity theory of prejudice toward female leaders. Psychological Review: p. 573-598.

Eagly, A. H. - Carli, L. L. (2007): Women and the Labyrith of Leadership. Harvard Business Review, Sept.: p. 63-71. 
Eagly, A. H. et al. (2000): Social role theory of sex differences and similarities: a current appraisal. in: $\mathrm{T}$. Eckes - H. Trautner (eds.): The Developmental Social Psychology of Gender: p. 23-174.

Ely - Padavic (2007): A Feminist analysis of Organizational Research on Sex Differences. Academy of Management Review: p. 1121-1143.

Ertac - Gurdal (2012): Deciding to decide: Gender, leadership and risk-taking in groups. Journal of Economic Behavior \& Organization: p. 24-30.

Esarey, J. - Leslie, S.-B. (2014): Gender, Corruption, and Accountability: Why Women are (Sometimes) More Resistant to Corruption. Tennessee: Working paper presented at University of Tennessee

European Comission (2016): Gender Equality. Retrieved from Justice

Eurostat (2015): (http://ec.europa.eu/justice/gender-equality/). http://ec.europa.eu/justice/gender-equality/.

Everett, L. - Thorne, D. - Danehower, C. (1996): Cognitive moral development and attitudes toward women executives. Journal of Business Ethics: p. 1227-1235.

Falkenberg (1990): Improving the Accuracy of Stereotypes Within the Workplace. Journal of Management: p. 107-118.

Farrell-Hersch (2005): Additions to corporate boards: the effect of gender. Journal of Corporate Finance: p. 85-106.

Featherstone, B. (2004): Fathers Matter: A Research Review. Children and Society: p. 312-319.

Fondas, N. (1997): Feminization Unveiled: Management Qualities in Contemporary Writings. Academy of Management Review: p. 257-283.

Frank - Lambsdorff - Boehm (2011): Gender and Corruption: Lessons from Laboratory Corruption Experiments. European Journal of Development Research: p. 59-71.

Fullagar et al. (2003): Managerial sex-role Stereotyping: A cross-cultural analysis. International Journal of Cross Cultural Management: p. 93-107.

Gallego-Álvarez - García-Sanchez - RodríguezDominguez (2009): The influence of gender diversity on corporate performance. Spanish Accounting Review: p. 53-88.

Gherardi, S. (1994): The gender we think, the gender we do in our everyday organizational lives . Human Relations: p. 591-610.

Haslam - Ryan (2008): The road to the glass cliff: Differences in the perceived suitability of men and women for leadership positions in succeeding and failing organizations. Leadership Quarterly: p. 530-546.

Haslam - Ryan - Kulich - Trojanowski-Atkins (2010): Investing with Prejudice: The Relationship Between Women's Presence on Company Boards and Objec- tive and Subjective Measures of Company Performance. British Journal of Management: p. 484-497.

Heilman, M. (1983): Sex Bias in Work Settings: The Lack of Fit Model. Research in Organizational Behavior: p. 269-298.

Heilman, M. (1995): Sex stereotypes and their effects in the workplace: What we know and what we don't know. Journal of Social Behavior \& Personality: p. 3-26.

Heilman, M. (2001): Description and prescription: How gender stereotypes prevent women's ascent up the organizational ladder. Journal of Social Issues: $p$. 657-674.

Hersey et al. (2008): Management of Organizational Behaviour: Leading Human Resources. Upper Saddle River, N.J.: Prentice-Hall

Hillman - Parthiban - Bloom (2007): Investor activism, managerial responsiveness, and corporate social performance. Strategic Management: p. 91-100.

Hitt - Harrison - Ireland - Best (1998): Attributes of Successful and Unsuccessful Acquisitions of US Firms. British Journal of Management: p. 91-114.

Hoffman, R. M. - Borders, L. (2001): Twenty-five years after the Bem Sex-Role Inventory: A reassessment and new issues regarding classification variability. Measurement and Evaluation in Counseling and Development: p. 39-55.

Holst, E. - Kirsch, A. (2014): Financial sector: Upward trend in share of women on corporate boards progressing only in small steps. DIW Economic Bulletin: p. 17-25.

House, R. - Javidan, M. - Hagnes, P. - Dorfman, P. (2002): Understanding cultures and implicit leadership theories across the globe: an introduction to project GLOBE. Pergamon, Journal of World Business: p. 3-10.

Huse et al. (2009): Boards of Directors' Contribution to Strategy: A Literature Review and Research Agenda. Corporate Governance: An International Review: p. 292-306.

Ibarra, H. - Carter, N. M. - Sylva, C. (2010): Why Men Still Get More Promotions than Women? Harvard Business Review

Jianakoplos - Bernasek (1998): Are women more risk averse? Economic Inquiry: p. 620-630.

Joecks - Pull - Vetter (2012): Gender Diversity in the boardroom and Firm Performance: What Exactly Constitutes a "Critical Mass". Journal of Business Etics: p. 1-40.

Judge, T. A. - Bono, J. E. (2000): Five-Factor Model of Personality and Transformational Leadership. Journal of Applied Psychology: p. 751-765.

Judge, T. A. - Piccolo, R. F. (2004): Transformational and Transactional Leadership: A Meta-Analytic 
Test of Their Relative Validity. Journal of Applied Psychology: p. 755-768.

Kanter, $R$. (1977a): Men and women of the organization. New York: Basic Books

Kanter, $R$. (1977b): Some effects of proportions on group life: Skewed sex ratios and responses to token women. The American Journal of Sociology: p. 965-990.

Kark, $R$. (2004): The transformational leader: who is (s) he? A feminist perspective. Journal of Organizational Change Management: p. 160-176.

Katila - Meriläinen (1999): A Serious Researcher or Just Another Nice Girl?: Doing Gender in a Male-Dominated Scientific Community. Gender, Work \& Organization: p. 163-173.

Kite et al. (2008): Gender stereotypes. in: Denmark, F. (2008): Psychology of Women: A Handbook of Issues and Theories. London: Praeger: p. 205-236.

Koenig - Eagly - Mitchell - Ristikari (2011): Are leader stereotypes masculine? A meta-analysis of three research paradigms. Psychological Bulletin: p. 616642.

Konrad, A. M. - Kramer, V. (2006): How many women do boards need? Harvard Business Review, 84(12): p. 22.

Konrad, A. M. - Kramer, V. - Erkut, S. (2008): Critical mass. Organizational Dynamics: p. 145-164.

Kornau, A. M. - Festing, M. (2013): The impact of male-oriented organisational cultures on the career advancement of female managers: A review and a framework for future research.

Kotter, J. P. (2001): What Leaders Really Do . Harvard Business Review

Krishnan - Park (2005): A Few Good Women - On Top Management. Journal of Business Research: p. 1712-1720.

Lawler, D. E. (1995): Empowering Service Employees. MIT Sloan Management Review: p. 1-12.

Levi, M. - Li, K. - Zhang, F. (2014): Director gender and mergers and acquisitions. Journal of Corporate Finance, Oct.: p. 185-200.

Lewis - Simpson (2010): Meritocracy, difference and choice: women's experiences of advantage and disadvantage at work. Gender in Management: An International Journal: p. 165-169.

Liff - Ward (2001): Distorted views through the glass ceiling: the construction of women's understandings of promotion and senior management positions. Gender, Work \& Organization: p. 19-36.

Lippa, R. (2005): Gender, Nature, and Nurture. Mahwah, NJ.: Erlbaum

Lückerath-Rovers, M. (2013): Women on boards and firm performance. Journal of Management and Governance: p. 491-509.
Mansbridge (2005): Quota Problems: Combating the Dangers of Essentialism. Politics \& Gender: p. 622683.

Marshall, J. (1995): Gender and management: a critical review of research. British Journal of Management: p. 553-562.

Mathieu, C. (2009): Practicing gender in organizations: the critical gap between practical and discursive consciousness. Management Learning: p. 177-193.

Mavin, S. (2008): Queen Bees, Wannabees and Afraid to Bees: no more 'best enemies' for women in management? British Journal of Management: p. 575584.

McKinsey \& Company (2012): Women matter: Making the breakthrough. McKinsey \& Company

McTavish - Miller (2009): Management, leadership and gender representation in UK higher and further education. Gender in Management: An International Journal: p. 178-194.

Meyerson, D. (2000): A modest manifesto for shattering the glass ceiling. Harvard Business Review: p. 126-136.

Miller, G. (2002): The frontier, entrepreneurialism, and engineers: women coping with a web of masculinities in an organizational culture . Culture and Organization: p. 145-160.

Morrison - White - Velsor, V. (1987): Breaking the Glass Ceiling: Can Women Reach the Top of America's Largest Corporations?

Murrell, A. J. - James, E. H. (2001): Gender and Diversity in Organizations: Past, Present, and Future Directions. Sex Roles: p. 243-257.

Nagy, B. (2001): Női menedzserek. Budapest: Aula

Nagy, B. (2007): A társadalmi nem szerepe a vezetésben Magyarországon (The role of gender in management in Hungary). Budapest: Aula Kiadó

Nagy, B. - Primecz, H. (2010): Nók és férfiak a szervezetben - kísérlet a mítoszok eloszlatására. Vezetéstudomány (Budapest Management Review): p. 2-17.

Nagy, B. - Vicsek, L. (2008): The evaluation of male and female managers at a local municipality in Hungary. Gender in Management: An International Journal: p. 36-50.

Niederle - Vesterlund (2007): Gender Differences in Competition. Negotiation Journal: p. 447-463.

Nielsen - Huse (2010): The Contribution of Women on Boards of Directors: Going Beyond the Surface. Corporate Governance an International Review: p. 136-148.

Pfeffer - Salancing (1977): Who Gets the Power. Organizational Dynamics: p. 3-21.

Phalen (2000): "Pioneers, girlfriends and wives:" An agenda for research on women and the organization- 
al culture of broadcasting. Journal of Broadcasting \& Electronic Media: p. 230-247.

Powell, G. N. (2012): Six ways of seeing the elphant: the intersection of sex, gender, and leadership. Gender in Management: An International Journal: p. 119141.

Powell, G. N. - Butterfield (1989): The "good manager": Did androgyny fare better in the 1980s? Group and Organization Studies: p. 216-233.

Powell, G. N. (1999): Reflections on the glass Ceiling: Recent Trends and Future Prospects. in: Powell, G. N. (1999): Handbook of Gender and Work. Thousand Oaks: Sage: p. 325-345.

Rafferty, A. E. - Griffin, M. A. (2004): Dimensions of transformational leadership: Conceptual and empirical extensions. The Leadership Quarterly: p. 329 354.

Rhode - Packel (2010): Glass Ceilings and Dead Ends: Professional Ideologies, Gender Stereotypes, and the Future of Women Lawyers at Large Law Firms. University of Denver Sturm College of Law University of Denver Sturm College of Law: p. 10-58.

Ridgeway, C. (1991): The social contruction of status value: gender and other nominal characteristics. Social Forces: p. 367-386.

Ridgeway, C. (2009): Framed by gender: How gender inequality persist in the modern world. New York: Oxford University Press

Rose (2007): Does female board representation influence firm performance? The Danish evidence. Corporate Governance: An International Review: $p$. 404-413.

Rosener, J. B. (1990): Women Lead. Harvard Business Review: p. 119-125.

Rutherford, S. (2001): Organizational culture, women managers and exclusion. Women in Management Review: p. 371-382.

Sargent, A. (1981): The Androgynous Manager. AMACOM

Sayers, $R$. (2012): The cost of being female: critical comment on block. Journal of Business Ethics: p. 519-524.

Schein, E. et al. (1996): Think manager - Think male: a global phenomenon? Journal of Organizational Behavior: p. 33-41.

Schein - Mueller (1992): Sex role stereotyping and requisite management characteristics: A cross cultural look. Journal of Organizational Behavior: p. 439447.

Schein, E. (2004): Organizational Culture and Leadership. San Francisco, CA: Jossy-Bass

Schein, V. E. (2001): A Global Look at Psychological Barriers to Women's Progress in Management. Journal of Social Issues: p. 675-688.
Schwartz, S. - Rubel-Lifschitz, T. (2009): Cross-national variation in the size of sex differences in values: effects of gender equality. Journal of Personality and Social Psychology: p. 171-185.

Simpson, $R$. (2000): Gender mix and organisational fit: how gender imbalance at different levels of the organisation impacts on women managers. Women in Management Review: p. 5-18.

Simpson - Ross-Smith - Lewis (2008): Merit, special contribution and choice. Gender in Management: An International Journal: p. 198-207.

Singh - Vinnicombe (2004): Why So Few Women Directors in Top UK Boardrooms? Evidence and Theoretical Explanations. Corporate Governance: An International Review: p. 479-488.

Sung, H.-E. (82): Fairer Sex or Fairer System? Gender and Corruption Revisited. Social Forces: p. 703-723.

Swami et al. (2001): Gender and corruption. Journal of Development Economics: p. 25-55.

Tannenbaum, $R$. - Schmidt, W. (1973): How to choose a leadership pattern. Harvard Business Review: p. 162-180.

Terjesen, S. - Singh, V. (2008): Female presence on corporate boards: a multi-country study of environmental context. Journal of Business Ethics: p. 55-63.

Terjesen, S. - Sealy, R. - Sing, V. (2009): Women Directors on Corporate Boards: A Review and Research Agenda. Corporate Governance: An International Review: p. 320-337.

Tienari, J. et al. (2013): And then there are none: on the exclusion of women in processes of executive search. Gender in Management: An International Journal: p. $43-62$.

Timberlake, S. (2005): Social capital and gender in the workplace. Journal of Management Development: $p$. 34-44.

Torchia, M. - Calabro, A. - Huse, M. (2011): Women Directors on Corporate Boards: From Tokenism to Critical Mass. Journal of Business Ethics: p. 299317.

Tóth, H. (2005): Gendered dilemmas of the work-life balance in Hungary. Women in Management Review: p. 361-375.

Unger (1979): Toward a redefinition of sex and gender. American Psychologist: p. 1085-1094.

van Vianen - Fisher (2002): Illuminating the glass ceiling: The role of organizational culture preferences. Journal of Occupational and Organizational Psychology: p. 315-337.

Vicsek, L. (2002): The Influence of Class Origins and Gender on Life Chances. Review of Sociology, 8(1): p. 55-78.

Vinkenburg, C. J. - Engen, M. L. - Eagly, A. H. - Johannesen-Schmidt, M. C. (2011): An exploration 
of stereotypical beliefs about leadership styles: Is transformational leadership a route to women's promotion? The Leadership Quarterly: p. 10-21.

Wajcman, J. (1998): Managing like a Man. Pennsylvania Penn State University Press

Wajcman, J. (2011): It's Hard to be Soft: Is manangement Style Gendered? (Vols. Szervezet, menedzsment és nemek). (N. Bea, Ed.) Budapest: Aula

Wangnerud, L. (2014): Corruption as an obstacle to women's political representation: Evidence from local councils in 18 European countries. Party Politics: p. 1-16.

Webster - Berger (2006): Expectations, Status and Behavior. in: J. Burke (2006): Contemporary Social Psychological Theories. Stanford: Stanford University Press: p. 268-292.
Wicks, D. - Bradshaw, P. (1999): Gendered organizational cultures in Canadian work organizations: implications for creating an equitable workplace. Management Decision: p. 372-381.

Wood, W. - Eagly, A. (2010): Gender. in: Fiske, S. T. et al. (eds.): Handbook of Social Psychology. New York: Wiley: p. 629-667.

Yoder, J. (2001): Making Leadership Work More Effectively for Women. Journal of Social Issues: p. 815828.

Yu Liu, Z. W. (2014): Do women directors improve firm performance in China? Journal of Corporate Finance: p. 169-184.

Zahidi - Ibarra (2010): The corporate gender gap report 2010. Geneva: World Economic Forum

\section{AUTHORS OF THIS ISSUE}

Felsmann, Balázs, assistant research fellow, Corvinus University of Budapest; Révész, Éva, assistant professor, Corvinus University of Budapest; Gergelyné Kása, Marianna, $\mathrm{PhD}$ candidate at the Corvinus University of Budapest, vice president at Commerzbank Zrt, Corporate Banking; Taródy, Dávid, assistant research fellow, Corvinus University of Budapest; Ferincz, Adrienn, assistant lecturer, Corvinus University of Budapest; Dunavölgyi, Mária, director, External Relations Board of Corvinus University of Budapest 